\title{
Kiire ja tervislik toit - kas alati ka usaldusväärne? Kaubanduslikud kuulujutud tänapäeva tarbimisühiskonnas ${ }^{1}$
}

\begin{abstract}
Eda Kalmre
Teesid: Artiklis käsitletakse kahe Eestis levinud toiduteemalise kuulujututsükli teket ja algupära, nendes kuuldustes, aruteludes, kommentaariumides ja artiklites esile tulevaid erinevaid seisukohti tänapäeva tarbimise ja kaubanduse kohta, inimeste probleeme, hirme ja stereotüüpseid uskumusi. Esimene käsitletav nn kaubanduslik kuulujutt salatipesust ja muudest poepettustest - on Eesti algupäraga. Nimelt hakkas 2006. aastast Eesti suhtlusvõrgustikes ja hiljem ka ajakirjanduses levima kuuldus, et siinsetes poekettides pakutakse tarbijatele vanu salateid, millest on kaste välja pestud ja uuega asendatud. Teine (tõenäoliselt USA algupäraga) rahvusvahelise turu ja kaubandusega seotud kuuldus aktiveerus Eestis 2013. aasta alguses sotsiaalvõrgustikus levinud kettkirja kaudu. Nimelt levis seal kettkirjana hoiatusjutt beebiporgandite kahjulikkusest.
\end{abstract}

Märksõnad: kaubanduslik legend, kuulujutt, tervislik toitumine, toiduvõltsimine, uskumus, uudisfolkloor, vandenõuteooria

Tänapäeva üleilmsetes meedia- ja suhtlemisvõrgustikes levib kõmu teatud kahtlase toote või kaubamärgi kohta väga kiiresti. Viimaseid globaalseid toiduga seotud skandaale Euroopas oli 2012.-2013. aastal Suurbritanniast alguse saanud pahandus hobuselihaga. (Hein 2013) Viimane on inimtoiduna paljudes nüüdiskultuurides täiesti vastuvõetamatu, mistõttu selle tahtmatut/kogemata söömist peetakse lubamatuks ja selle söömisele eksitajat kurjategijaks. Skandaali olemus seisnes selles, et veiseliha pähe pakuti mitmetes valmistoodetes hobuseliha, asi läks koguni nii kaugele, et DNA-testide jms abil leiti hobuseliha nendes toodetes, kus seda ei pidanuks olema: IKEA lihapallides, lihapirukates, salaamivorstis jm.

Osalt oli siin tegemist kauplejate tahtmatu-teadmatu tegevusega. Üks nendes aruteludes ja artiklites tõstatatud küsimus seisneski selles, et tänapäeva suurtootmise ja keeruliste tarneahelate puhul ei tea poeketid ka ise, kust nende toodang tuleb ja mida see sisaldab. Teisalt oli tegemist suurtootjate-poolse tahtliku toiduvõltsimisega. Nii reaalsed juhtumid kui ka nendega kaasas käivad 
kuuldused ja hirmud mõjutasid sel ajal suuresti tarbijate valikuid ja otsuseid. Näiteks Suurbritannia ja Põhja-Iiri Ühendkuningriigis läbi viidud küsitluse kohaselt väitis ligi kolmandik täiskasvanud elanikest, et on hobuselihaskandaali tõttu lakanud söömast valmistoite, seitse protsenti teatas, et ei söö enam liha üldse. Üks skandaali tulemus oli see, et tarbijad hakkasid oma toidukorvide sisu valima mitte enam hinna vaid tootja usaldusväärsuse järgi. Näiteks Suurbritannias võitsid sellest eelkõige kõrgema hinnaskaala ja usaldusväärsema kvaliteediga väiketootjad. (Lucas 2013 jt) Skandaali keskpunktist eemale jäänud Eestis toimis asi aga isegi mõneti vastupidiselt, äratades tarbijates hoopis uudishimu ja huvi hobuseliha sisaldavate toodete vastu (Reporter 2013).

Suurbritanniast alanud skandaal levis paljude uudistekanalite ning sotsiaalvõrgustike kaudu Euroopas väga kiiresti, moodustades sündmust erinevatest külgedest avavaid võrgustikke. Eesti ajakirjandus avaldas tõlkelisi lugusid olukorra kohta Suurbritannias ning mujal Euroopas, sellele lisandusid kohalikku lihatootmist ja kaubandust käsitlevad lood. Tavainimeste seisukohad, arvamused ja eelarvamused avaldusid lugude kommentaariumides ja sotsiaalmeedias, osa sellest ka naljade ja pilapiltide vormis.

Kui varem oli uurijatel suulises käibes ringlevaid lühiajalisi kuulujutte üsna raske fikseerida, veel vähem õnnestus tabada erinevate kuulduste arenguid ja algupära, siis tänapäeval teeb internet oma sotsiaalmeedia, digiajakirjanduse

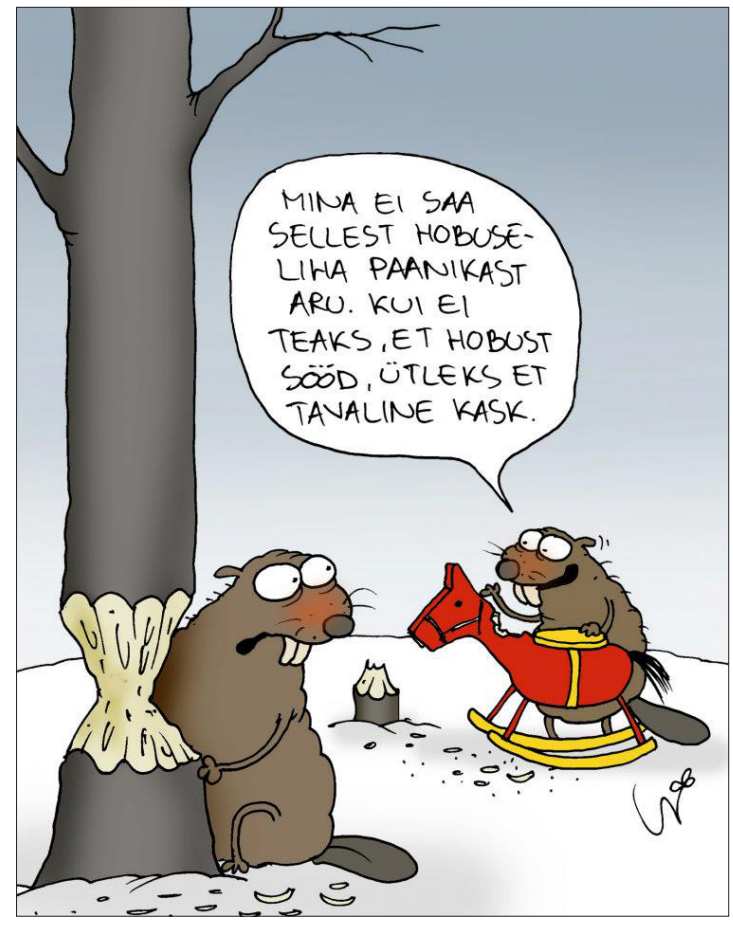
ning otsingumootoritega selle tunduvalt lihtsamaks. Käesolevas artiklis käsitlen kahe Eestis levinud toiduteemalise kuulujututsükli algupära ja teket ning nendes kuuldustes, aruteludes, kommentaariumides ja artiklites esile tulevaid seisukohti tänapäeva tarbimise ja kaubanduse kohta, inimeste probleeme, hirme ja uskumusi.

Illustratsioon 1. Hobuseliha paanika ajal Postimehes (6. märts2013)ilmunudUrmas Nemvaltsi karikatuur (http: / / arvamus. postimees.ee/1161054/paeva-karikatuurarusaamatu-hobusepaanika). Pilapilt levis pärast ilmumist ka Facebookis. 


\section{Kaubanduslikud legendid, kuulujutud ja uudisfolkloor}

Rahvajutud ebausaldusväärsest toidust on ilmselt sama vanad kui esimesed kõrtsid, ja pärinevad ajast, mil inimesed kaotasid kontrolli oma toidulaua üle, ei tootnud ega valmistanud enam kogu toitu ise. Need jutud on omamoodi vastukajad globaliseeruva maailma inimeste elutingimuste muutumisele, tehnilistele uuendustele, rangematele puhtusenõuetele, immigratsioonile.

Näiteks hiina ja india restoranide levikuga seoses hakkas juba 1950. aastatel New Yorgis ringlema nn tühja purgi motiiv (vt nt Klintberg 1983: 155). See tähendab, et väidetavalt leiti nende restoranide tagant tühje kassi- ja koeratoidu purke ning nende loomade jäänuseid. See etnotsentristlik kuulujutt, mis tugines universaalsele ideele, mille kohaselt võõrast kultuurist pärit inimestele omistatakse kohalikus kultuuris vastuvõetamatute (lemmikloomade jms) loomade söömist, levis hiljem kogu Euroopas ja Eestiski 1990. aastate alguses, kui siin avati esimesed välismaalaste toidukohad.

Moodsa ühiskonna kaubanduslikud legendid ja kuulujutud muutusid uurimisainesena populaarseks 1980. aastatel, ehkki üksikuid käsitlusi (Bell 1976; Domowitz 1979; Fine 1979 jt) oli ilmunud juba varem. Mõiste 'kaubanduslikud legendid' (mercantile legends) ja kuulujutud ${ }^{2}$ võttis kasutusele Gary Alan Fine (1985). Tema järgi on kaubanduslikud legendid tänapäeva legendide (contemporary legends) e linnalegendide (urban legends) allkategooriad, mis käsitlevad juttude tegelastena äriettevõtteid/korporatsioone. Tüüpiliselt eeldavadki kaubanduslikud legendid seost äriettevõtte ja mõne haavatava sündmuse vahel. Fine'i järgi võib kaubanduslikke legende käsitleda kui minidokumentaaldraamasid, kus midagi hirmutavat juhtub naiivse ohvriga, kes kaupa ostab/tarbib. Autor klassifitseerib sellised äriettevõtteid käsitlevad legendid sisu põhjal kolme kategooriasse: 1. kurjad, 2. petjad ja 3. hoolimatud äriettevõtted/korporatsioonid (Fine 1985: 64). Artikli autor, vaadelnud Ameerika traditsioonis paljusid taolisi jutte ja nende folkloristlikke käsitlusi, sõnastas kõiki neid siduva korrapära - Koljati efekti. S.t, et nendes kaubanduslikes legendides ja kuulujuttudes esile tulnud ameeriklaste usaldamatus ja hirmud olid valdavalt suunatud suurtootjate ja -korporatsioonide poole. (Fine 1985: 65) Mõned näited Ameerika traditsioonis 1970.-1980. aastate populaarsematest ebausaldusväärsetest suurfirmadest ja nende kohta levinud kuulujuttudest: McDonalds (ussid hamburgeris), Coca-Cola RC (hiir pudelis), Hubba-Bubba (ämblikumunad närimiskummis) jpt. Nende kompaniide üldtuntus ja psühholoogiline domineerimine aitas kaasa uskumuste tekkimisele nende firmade pahatahtlikkuse kohta. Mõnel juhul võivad kuuldused keskenduda ka näiteks inimestele (sagedamini firmajuhtidele), kes avalikkuse arvates esindavad mingit ettevõtet, ideoloogiat või arusaama (Fine 1985: 65). 
Kaubanduslike legendide ja kuulujuttude levitamisel on olnud suur osa ajakirjandusel. Samas on Gary Alan Fine märkinud, et ajakirjandus ise ei loo ega tekita neid lugusid. Ta peegeldab ja interpreteerib suulisest traditsioonist pärit lugusid, ühendab, ühtlustab ja suunab neid arutelusid mitmesse suunda. Kuigi meedia paisutab inimeste hulka, kes seda on kuulnud, ja ühtlustab/homogeniseerib populaarset mälu, ei ole teada, et ühestki kaubanduslikust kuulujutust oleks kirjutatud enne kui nad on juba (laialt) rahva hulgas ringlemas. Ameerika materjali põhjal on Gary Alan Fine arvanud, et kuigi televisioonis ja ajalehtedes ilmunud lood on sageli halvustavad, ei nimeta nad süüdlast enne, kui rääkijate populaarne/ühtne konsensus on selles osas saavutatud (Fine 1985: 67). ${ }^{3}$ Kuulujutud keskenduvadki alati süüdlase leidmisele, ja üldjuhul saavutab kuulujutt oma efektiivsuse siis, kui üks sihtmärk esineb paljudes ühe loo variantides ning see vastastikku jagatud informatsioon loob reaalsusest enamust rahuldava kooskõlastatud arusaama. Jutu leviku käigus toimub jutu ühtlustamine, teravdamine ja assimileerumine. Viimane tähendab kuulujutu sobitumist kuulajate ettekujutustega, mäluga, nende intellektuaalsete ja emotsionaalsete vajadustega (Allport \& Postman 1947: 75-98, 99-100; Neubauer 1999: 166).

Kuuldused mingi suurtootja vandenõust tarbija vastu ületavad ajakirjanduses igal juhul uudisekünnise, ja tundub, et iga ajakirjanduslik käsitlus omakorda justkui kinnitab ja põhjendab inimeste huvi ja kahtlusi ning pakub selleks lisaainest. Frank Russell (2011) tõi tänapäeva folkloori uurimisse mõiste - newslore (uudisfolkloor), mis lubab näha kogu sarnast diskursust tänapäeva meedia toimimispraktikates. Nimelt võib mingi konkreetse ärevust tekitava kuulduse või skandaalse sündmuse ümber tekkinud uudisfolkloor tänapäeva meedias ja suhtlusvõrgustikes võtta väga erinevaid vorme: naljad, linnalegendid, kuulujutud, digitaalselt töödeldud pildid, libauudised, lauluparoodiad, poliitilised ja kommertslikud teadaanded, uudislood, artiklid, koomiksid, pildiseeriad ning lühikesed märulifilmid jmt. (Russell 2011: 7)

Kui varem keskendusid kaubanduslikud kuulujutud mingitele etnilistele hirmudele, populaarsetele toodetele, eelistatult rikastele suurfirmadele, kelle puhul tundusid jutud nende õelusest ja kasuahnusest või etnilisest vandenõust kõige usutavamad, siis järgnevate juhtumite käsitlemisel lähtun hüpoteesist, et 21. sajandil näib kuulujutte põhjustavat rohkem kaasaegse infoühiskonna ekspansiivne loomus, info igapäevane kättesaadavus ja kiirus ning vahelduvus (vt ka Langemets 1999), mis teeb raskeks (või koguni välistab) selle sisusse süvenemise.

Teisalt on nende toitumisalaste kuulujuttude põhjustajateks ilmselt ka tänapäeva tarbimisühiskonna inimeste üha suurenenud vajadustest ja rikkusest, vähenenud ajaressursist ja tervislikkuseihalusest põhjustatud ärevus ning kahtlused. 


\section{Kuulujutud salatipesust Eesti kauplustes}

Poest ostetud valmistoiduna on salat tänapäeva aina piiratuma ajaressursiga inimeste hulgas ilmselt üha populaarsem. Suuremad ja väiksemad poeketid pakuvad kiiresti rikneva ja lühikese tarbimisajaga salateid nii pakendatult kui ka kaalukaubana.

Tõenäoliselt 2005. aastal ${ }^{4}$ hakkas Eesti suhtlusvõrgustikes ja hiljem ka ajakirjanduses levima kuuldus sellest, et siinsetes poekettides pakutakse tarbijatele vanu salateid, millest on riknenud kaste välja pestud ja värskega asendatud.

See kuuldus käivitas aastail 2006-2015 ajakirjanduses ja sotsiaalmeedias diskussiooni, kus igal osalejal oli arvamus, mis tugines osalt tema enda kogemusele ja uskumustele, osalt kuuldud/omandatud informatsioonile. Nii salati kui ka muude toodete osas avaldasid oma seisukohti nii tootjad, asjatundjad kui ka tavatarbijad. Viimaste hulgas oli nii väite uskujaid kui ka mitteuskujaid. Igal juhul tõstatas see tarbijate arutelu poodide ja poekettide usaldusväärsuse ning neis müüdavate kaupade värskuse teemal.

Salatipesu kohta käivaid artikleid ja uudislugusid ilmus Õhtulehes, Postimehes, Tartu ja Pärnu Postimehes, Delfi Ärilehes, Virumaa Teatajas jm. Tänaseks on selle teema üle arutletud juba kümmekond aastat ja arutatakse veel 2015. aastalgi Buduaari ja Delfi Naisteka ning Soccernet ja Nupi foorumites, blogides (Tark ostja, Lipsuke jt) ning mitmetes Facebooki kogukondades. Erinevate artiklite järel ning sotsiaalmeedias ilmus kümne aasta jooksul ligemale 500 kommentaari. Need kommentaarid ja artiklid ongi järgneva kuulujutu tähenduste avamise allikmaterjaliks.

Kuulujutud on enamasti seotud eelarvamustega ning nende üks iseloomulikumaid tunnusjooni on läbirääkimine üldiselt aktsepteeritava süüdlase leidmiseks, kellest saab/tehakse neis juttudes patuoinas (Neubauer 1999: 4). Tõenäoliselt esimeses sel teemal 2006. aastal Delfi Ärilehes ilmunud artiklis "Kas poodides töötavad salatipesijad?" (Taim 2006) saavad sõna mitmete Eesti suuremate toidukaupluste esindajad (Rimi, Prisma, Selver ja Grossi Toidukaubad), kes kõik lükkavad kuulduse salatipesust otsustavalt ümber. Samale artiklile järgnenud kaheksakümne viies lugejakommentaaris leiavad nii kiitmist kui toiduvõltsimise kahtlusalustena ära märkimist paljud kauplused, sealhulgas ka enamik intervjuu andnud kauplusi. Kui jälgida selle ja järgnevate artiklite kommentaare, tekitavad tarbijates usaldamatust mitte ainult salatipesu (salatite värskendamine uue kastmega) ja salatite komponendid (see kas neid tehakse ikka värsketest komponentidest) ning see, kuidas poed tulevad toime salatite lühikese tarneajaga, vaid ka paljud muud müüjate väidetavad kelmused, mille eesmärk on müüa ostjatele vananenud ja ebakvaliteetset kaupa kõrge hinnaga. 
Kommentaariumis tulevad arutlusele kõik need teemad. Kõige rohkem konkreetseid ja karme nii isiklikele kogemustele kui ka kuuldustele tuginevaid süüdistusi on 2006. aasta artikli kommentaarides suunatud Grossi toidupoodide aadressil.

raudselt on olemas salatipesijad. grossi toidupoes kull tean sest üks tuttav on seal tööl selles ametis (juhan 06.01.2006)

Käisin varem meelsasti Grossi poes sisseoste tegemas. Paar kuud tagasi ostsin perele kotlette "mahe" ja sü̈̈es leidsin kotletist neli kalkuni kollast musta äärega küünt. Jube! Teavitasin sellest ka kaupluse müüjaid. Lõpetasin sisseostude tegemise ja käin meelsasti kõrvalasuvas Konsiumi poes, sealt saab kotlette lisandita. (ida-virumaalt 06.01.2006)

Grossi kaubad on tõesti alla igasugu arvestust kukkunud. Kvaliteeti pole enam ollagi. Varem ostsime samuti kogu kauba sealt poodidest. Nüüd ostame kauba Helter'ist, kvaliteet märgatavalt parem. Kuulge poodnikud, pange kurat hinda juurde-aga ärge mü̈̈ge solki! (Lääne-Viru, 06.01.2006)

Selle ilmselt millalgi 2006. aastast alates kulmineeruma hakanud süüdistustelaine vastukäiguna tegi OG Elektra ja Grossi toidupoodide omanik Oleg Gross oma ajalehes Kuulutaja (14. okt 2011) avalduse, milles lubas miljonit eurot sellele, kes tõestab, et tema poes toimub salatipesu.

"Nende salatipesu juttude peale võtsin ükskord ise kätte ja proovisin kas tegelikult on ka võimalik halvaks läinud koor salatist välja pesta," rääkis Gross. "Võtsin sõela ja proovisin voolava vee all pesta. Midagi mõistlikku küll välja ei tulnud. Ma ei kujuta ette, kust sellised jutud tulevad. Ja mis oleks salatipesu mõte? Kui palju see salat ikka maksab? Kui koor välja uhada, jääb järgi põhiliselt kartul ja purgihernes - kõige odavamad komponendid. Milline on sellise ettevõtmise tööjõukulu? Ja kuidas organiseerida sellist asja suures ulatuses nii, et see kohe välja ei tule. Ma kinnitan täie vastutustundega-maksan miljon eurot sellele inimesele, kes tuleb minu juurde ja tõestab mulle ära, et tegeles meie firmas organiseeritult salatite pesemisega. Ma ei saa välistada, et müügil on olnud aegumistähtaja ületanud salateid, et salat on üle soolatud või pipardatud, kuid see pesemise jutt on küll puhas absurd.”(Ojaperv 2011)

See Oleg Grossi skandaalne avaldus ei jäänud eesti ajakirjandusel märkamata, ja paar päeva hiljem, 19. oktoobril 2011 ilmusid uudislood "Oleg Gross pakub miljoni sellele, kes tõestab salatipesu” Õhtulehes, Virumaa Teatajas, Pärnu Postimehes jm, andes põhjust poepettuste ja süüdlaste teema uuesti üles võtta 
ning kogudes sadades uusi lugejate kommentaare (Mets 2011 jt). Peaaegu neli kuud hiljem, 21. veebruaril 2012 ilmus Tartu Postimehes Kristiina Kruuse põhjalik kaheleheküljeline käsitlus salatipesu kuulujutu teemal. Juba käsitluse kõik pealkirjad ("Linnalegendid šokeerivad tõepäraga", "Linnalegendid ajavad toidutootjad naerma", "Salatipesu miljoniline leiutasu ootab siiani") lubavad arvata kirjutiste suunda, kus artikli autor määratleb kogu seda teemat tõepärata kuulujutuna, folkloorina. (Kruuse 2012) Kruuse artiklis saavad sõna tootjad, veterinaar ja toiduameti esindaja ning folkloristist kuulujutu-uurija. Ometi kui jälgida kõigi nende viimaste artiklite ja uudislugude kommentaare, peab nentima, et midagi ei ole muutunud: nii nagu 2006. aastal pärast esimest artiklit, on kommentaariumides kaupluste toiduvõltsimise teema endiselt aktuaalne, ja vahendatakse nii oma kogemusi kui ka "oma kõrvaga tuttavalt kuuldud" jutte. Kuigi negatiivseid näiteid tuuakse nii Selveri, Prisma kui ka Rimi kohta, on salatipesus ning muudes valskustes endiselt kõige rohkem otsese kahtluse all Grossi toidupoed. ${ }^{5}$

Tõestada seda ei anna aga iga vähegi mõtlev inimene saab aru, et need salatid seal VÄRSKETEST toorainetest tehtud ei ole. Minu arust kõige hullem koht on SELVER! Olen seal korduvalt igasugu sitta ostnud alustades halvaks ja hallitama läinud suitsukaladest, kuni aasta üleolnud kompotiga. Juba pikka aega olen vältinud seda toidupoodide ketti ja kui vahel harva sinna poodi juhtun, siis uurin silmad grillis tähtaegu jne. (ostja, 21.02.2012)

Pestakse või ei pesta aga s.ta võtab Grossi salat küll lahti, minul vähemalt. Kui osta Grossi sardelle või viinereid siis tihtilugu on nad juba järgmisel päeval külmkapis! Libedad, kuigi peaks kõlbama mitu päeva. Ja kokkuvõttes on Grossi omatoodang ja kauplused kõvasti alla käinud. Haisvad poed, muulastest müüjad ja paljugi veel. (tallinlane, 21.02.2012)

sama asi - 1 tuttav on grossis tööl, tallinnas. ja neil pidi küll toimuma salatipesu. aga aegunud solki mü̈̈akse tõeti peaaegu igal pool. nii selveris kui prismas. rimidest käin ainult sõpruse pst-l, endises city-s, seal pole küll kunagi solki saanud. aga ntx mustamäe prismas olen isegi paar $x$ saalitöötajalt peaaegu et sõimata saanud selle eest et juhtisin nende tähelepanu hallitanud toidukaupadele. (naine, 06.01.2012)

Kartulisalat, nagu muudki salatid, on olnud senini kodused toidud, mida iga perenaine ise komponeerib, doseerib ja maitsestab. Nõukogude kaubavaesel ajal oli eriti kartulisalat ja rosolje iga eestlase pidulaua kohustuslik toit, mida igas kodus ise valmistati. Niisugune salat sisaldas paljusid erineva päritolu ja 
värskusastmega komponente ning selle käitlemisest ja tarbimisest on perenaistel siiani kogemused ja mälestused. Käesoleva artikli autorgi mäletab, et kartulisalatit kutsuti nõukogude ajal ka 'nädala ringvaateks', sest peale värskete hakiti sinna sisse ka nädala jooksul külmkappi seisma jäänud toiduaineid. Nii elustusid ja segunesid selles kuulujutus tänapäeva inimeste nõukogude-aegsed kollektiivsed ja individuaalsed toidu ja kaubandusega seotud mälestused ja kogemused. See kuuldus osutab nõukogude-aegsele toidu säästliku kasutamise praktikatele, kus 'parim enne' ei tuntud, ja perenaine ise otsustas, kuidas seisma jäänud toitu perele serveerida, kas värsket koort juurde segades või vorstikesi enne grillimist pestes. Kui inimene kodus ise kontrollis oma toidulauda ja vastutas selle eest, siis nõukogude-aegne toidutööstus ja kaubandus põhjustasid küll tarbijates kahtlusi ning kuulujutte. Neid mäletati ja need elustusid seoses selle salatipesu kuulujutuga.

Kunagi ammu nõuka ajal töötas minu naine toidupoes. Siis oli küll nii, et suitsuvorstid kui hakkasid juba hallitama nühiti toiduõlise kaltsuga uuesti puhtaks. Toores liha soolati plastmassist piima kastisesse ja pärast mü̈̈di soolalihaks. Kanad kui olid juba siniseks läinud, viidi lähedal asuvasse sööklasse ja seal grilliti need ära. Ja siis läksid need kui soojad saiad. (ammu, 06.01.2006)

Kindlasti vastab tõele, et suurpoodides tuleb tähtaegu kontrollida, sest erinevad väljapanekud lähevad segi ja pole alati kindel, et kõik õigel ajal ära koristatakse. Salatipesu on aga veneaegne legend, sest praegu kirjutavad ketid vana kauba lihtsalt tootja arvetelt maha. Nad nimelt on dikteeriv pool. Vene ajal aga jamati sellepärast, et värske salati või hakkliha materjal pandi lihtsalt pihta. (sahib, 06.01.2006)

värskendamine ju kogu aeg olnud. Lähevad kanad haisema visatakse grilli, riknenud hakkliha läheb kottletideks, koledad pehmed värsked kurgid lendavad soolvette ja nii saab kõik riknenud toidu kõrgema hinnaga maha mü̈̈dud. Ei osta kunagi poest valmis toitu. (leo, 19. 10. 2011)

Järgnevatest kommentaaridest ilmneb ka, et poes kaalukaubana müüdav salat ei olnud oma kvaliteedi ja maitseomaduste poolest paljude meelest lähedanegi kodus tehtule. Sellepärast soovitasid paljud kommentaatorid salat endal valmistada, mööndes küll, et see on ajamahukas tegevus ja alati selleks aega ei jää.

iga norm perenaine teeb ise salati (mida värki, 06.01.2006) 
Olen alati imestanud, kuidas on võimalik nii maitsetuid salateid teha, nagu need on Selveris. Noh nü̈̈d on siis tõde päevavalgele tulnud. Iga väiksemagi söögitegemisoskusega inimene teeb kodus igal juhul maitsvamini. Aga millegipärast neid siiski ostetakse ja mitte vähe. (Ann, 06.01.2006)

Salatid on aga igal pool maitsetud. Tihti on kartul salatis poolkõva ja krõmpsub. Isegi Stockmanni kallis salat oli ükskord krõmpsuva kartuliga ja väga halb. Salatite tegijad justkui ise üldse ei maitseks oma salateid. Segatakse mingi halva majoneesiga või lihtsalt hapukoorega. Salati maitse sõltub suuresti aga kasutatavast hapukurgist. No igatahes kodus teen mina küll hoopis maitsvamaid salateid. (naine, 06.01.2012)

Nii tõstatus nendes kommentaarides mitu tänapäeva inimesi erutavat teemat. Esiteks kiirem, odavam ja küsitava kvaliteediga valmistoit vs kodus valmistatud kvaliteetne, aga aega nõudev toit. Teiseks kui nõukogudeaegse toidukaupade defitsiidi ajal oldi koduse toidu värskuse testimisel valmis usaldama oma maitset, siis nüüdsel moodsal ajal saab usaldada ainult pakendil olevat kuupäeva, ehk siis pakendatud toit (sh salatid) versus lahtine e kaalukaubana müüdav (kahtlasem ja kontrollimatu) toit. Kindlam ja turvalisem valik tundus pakendatud toit, mille kuupäeva saab kontrollida. Samal ajal mõistsid varasema ühiskondliku ja kaubandusliku kogemusega inimesed, kuivõrd ebapraktiline ja raiskav on kogu see tänapäevane kuupäevadest sõltuv kaubandus.

sinul vaene leidake on siis ju silmad päris ära grillinud kui sa midagi ei näe...See kuidas selveris iga päev meeletul hulgal toitu prügikasti loobitakse on lihtsalt jube ja kõik sellepärast et realiseerimis aeg möödas nii et kui ei tea pole vaja rääkida. tuleks ometi see aeg kiiremini kus mü̈̈ja saab ostjat valida, muide ma ei tööta poes. (no nii, 06.01.2006)

ma loodan siiski, et kõik vähegi loomale söödav, mis on tähtaja ületanud, armulikult näiteks koerte varjupaigale viiakse. neil pole küll praetud veidi kuivanud vorsti vastu midagi. (lore, 06.01.2006)

Linnalegendidele ja nendega seostuvatele kuulujuttudele on iseloomulik moraliseeriv sisu, neis hoiatatakse ja sunnitakse tähelepanule, vastasel juhul lõpeb asi peategelase jaoks halvasti. Tegelikult sisaldab ka kommentaariumides esile tulev kogu selle salatipesu teema kohta käiv rahvalik käsitlus palju moraliseerivaid ja konkreetseid toimimisõpetusi selle kohta, kuidas tuleks kvaliteetset ja tervislikku kaupa osta sooviv inimene oma igapäevaelus toime ainult kasumile orienteeritud müüja väikeste sulitempudega. Ostjana tuleb selles maailmas teada paljusid väikesi tarkusi ja olla väga tähelepanelik. 
Kes lahtiste silmadega poes ringi vaatab, tabab õige pea ära nõksud, mida ENAMUS poodidest praktiseerib: 1) värskemat leiba, saia saate riiuli KÕIGE KAUGEMAST( loe: kõige ebamugavamast) nurgast 2) piimatooted on reeglina kastis värsked ja vanemad ilusti segamini. tasub IGA pakki eraldi vaadata! 3) risk on osta n.ö. kohapealset "värsket" hakkliha. Keegi ei tee seda värskest lihast. 4) RIMIST ostetud grill kanatiibadest on kolmest korrast kahel kodus mikrouunis soojendades tulnud raipehaisu! 5) mitmes GROSSI poes mü̈̈akse kilekotti valmispakendatud puu-(köögi)vilja. Pea alati avastate kodus peale koti avamist OSAVALT sisse sokutatud mädaplönni. 6) heitke aeg-ajalt ka pilk kassaaparaadi tabloole, kui müüja kauba hindu läbi lööb (kehtib ka triipkoodi lugejate puhul!) Oktoobris mü̈̈s näiteks RIMI 17 kroonist import kurki 37 kr. Luunja kurgi pähe! Minu sõbraliku märkuse peale vastati, et jah oli tõesti selline aps. Eks tooge oma ostukviitung poodi, maksame vahe kinni.(korrektne oleks olnud vabandada KÕIGI klientide ees, kes pahaaimamatult end pügada lasid). 7) Salatite ja muude kiirelt riknevate toitude puhul jääb kahjuks alati risk. Tundlikku nina ja teravat silma oskaks ainult soovitada. (06.01.2006)

Tartu Rimis vaatasin ükskord soodushinna sildi all olevat sama toote eelmist hinnasilti ja ilmnes, et seal oli väiksem hind. Rimi töötajalt arupärimisele - ta lihtsalt vaikimisi eemaldas alumise hinna sildi ja kortsutas kokku. (heauskne, 06.01.2006)

Naer ja iroonia olukorra üle ning teadlikkus nende juttude pärimuslikust (folkloorsest) algupärast tundub olevat salatipesu meediadiskursusse (uudisfolkloori) integreeritud lahutamatu osa, mis väliselt justkui välistaks sedalaadi uskumusi. Lõppkokkuvõttes aga tundub, et uskumusjuttu ja huumorit siduv vaatenurk aitab näha ja siduda erinevaid argumente ja tähendusi, ning lõppkokkuvõttes isegi tugevdada usku jutu tõepärasusse, pannes vastased üha kirglikumalt ja põhjalikumalt oma väiteid põhjendama. ${ }^{6}$ 


\section{Beebiporgandid - kas tervislik või kahjulik toit}

Teine ülemaailmse turu ja kaubandusega seotud kuulujutt on alguse saanud tõenäoliselt Ameerika Ühendriikidest. Nimelt hakkas 2013. aasta alguses Eesti sotsiaalvõrgustikes, Facebookis jm levima hoiatav kettkiri beebiporgandite tervistkahjustavast toimest.

Beebi- ehk miniporgandite ${ }^{7}$ kui toote ajalugu ulatub tagasi 1980. aastateni, mil Ameerika ühiskonnas hakati suuremat tähelepanu pöörama tervislikule toidule. Neist sai moekaup Ameerika Ühendriikide kaubanduses 1980. aastatel, kui California juurviljakasvataja Mike Yorosek hakkas neid oma ebastandardsetest porganditest tootma. Kui muidu olid porgandid lihtsalt juurvili, siis nüüd sai neist bränd, mis pööras pea peale juurvilja senise tootmise, turustamise ja tarbimise strateegia. Väike puhastatud ja kohe tarbimiseks mõeldud juurvili sobis hästi üha rohkem aktualiseeruvasse tervisliku eluviisi ja toidu diskursusse. Beebiporgandid jõudsid USA supermarketitesse 1989. aastal ja tervislikust toidust sai USAs suur ja kasumlik tööstusharu. Järgnevalt mõned statistilised andmed selle toiduaine kasutamise võidukäigu kohta Ameerika Ühendriikides.

- USAs on aastas üle 172 milj tonni porgandeid lõigutud miniporganditeks.

- Beebiporganditest saadav kasum ületab 400 milj dollarit aastas. Ühest porgandist saab teha keskmiselt 3 miniporgandit, kui 4, siis saab tootja juba $30 \%$ kasumit.

- Kui hakati tarbima beebiporgandeid, siis suurenes porganditarbimine $33 \%$.

- Iga inimene tarbib neid rohkem kui 2 dollari eest aastas.

- 1999. aastal ületas beebiporgandite tarbimine tavalise porgandi tarbimise. 94\% USA tarbijatest ostsid beebiporgandeid.

- Beebiporgandeid tarbiti isegi rohkem kui värske salati segusid.

- Kuni 2000. aastani edestas miniporgandite tarbimise tõus USA toiduäris kõigi teiste toodete tarbimise kasvu. ${ }^{8}$

Pärast 2000. aastat hakkas beebiporgandite tarbimine USAs mõnevõrra langema, seetõttu algatati 2009. aastal seal suur turundus- ja reklaamikampaania, mis rõhutas ameeriklaste seniste toitumisharjumuste kahjulikkust ning uue tervisliku toidu ja elulaadi tulekut. Tollase reklaamikampaania juhtlause oli - söö beebiporgandeid nagu rämpstoitu. Selleks kujundati ümber kogu miniporgandite pakkumise strateegia. Lastele ja noortele mõeldes hakati neid sarnaselt kartulikrõpsude ja kommidega pakkuma väikestes värvikirevates pakendites. Linnadesse ilmusid spetsiaalsed beebiporgandite automaadid, kust neid pakikesi sai kiirtoiduna söömiseks kaasa osta. (World Carrot Museum) 


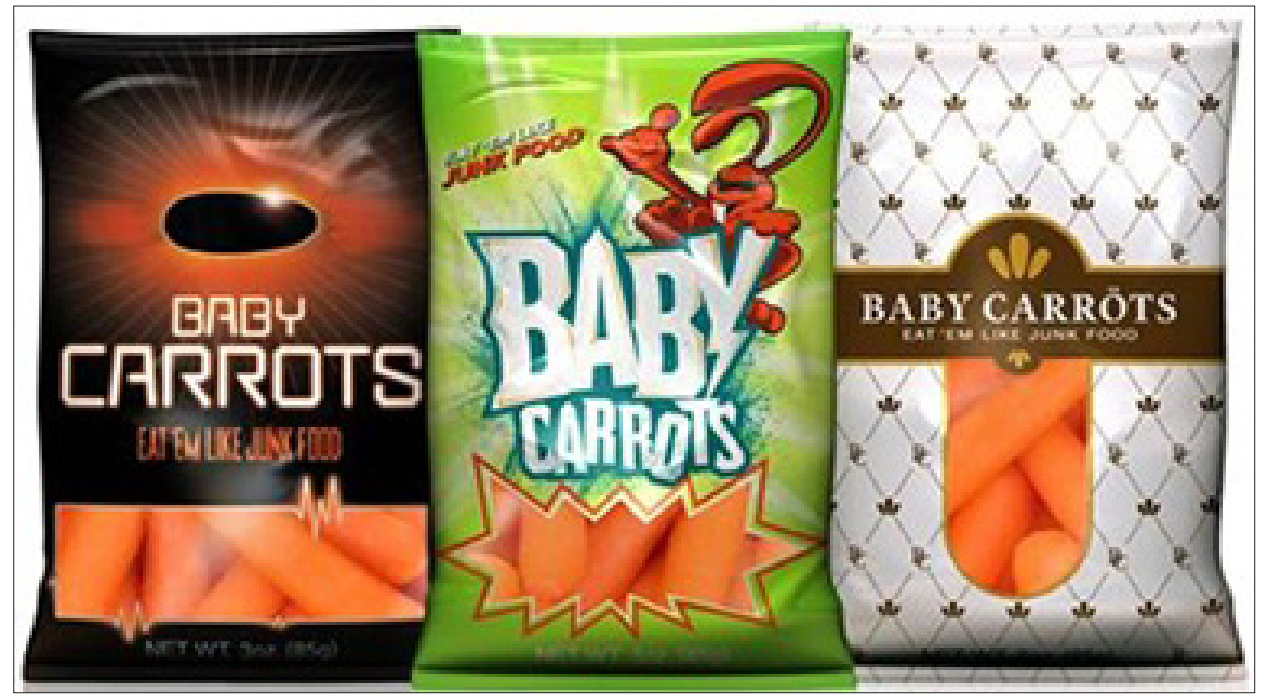

Illustratsioon 2. "Söö neid nagu rämpstoitu” - 2009. aastast sai beebiporganditest värvikirevates pakendites bränd (http: / / www.carrotmuseum.co.uk).

Kuulujutud beebiporgandite kahjulikkusest said Eestis alguse Facebooki kaudu levivatest kettkirjadest, kusjuures - nii nagu käesoleva artikli kirjutajal õnnestus selgitada - leviski hoiatuskiri eesti võrgustikes põhiliselt ingliskeelsena, tihti oli sellele lisatud miniporgandite foto. Kusjuures kirja edasisaatjaid ei tundunud häirivat, et selles on juttu Ameerika kaubast ja poekettidest ning saatja - Department of Life Education - kõlab küll asjalikult ja usaldusväärselt inglise keeles, kuid tõlkes - Eluõppe Osakond - tundub vajavat täpsemat määratlemist (kus selline allinstitutsioon asub, millega tegemist jne). Järgnevalt on ära toodud ühe sellise kirja tõlge.

Oht teie perekonnale

Eluõppe Osakonnalt ('From the Department of Life Education')

Beebiporgandid:

Järgnev informatsioon pärineb farmerilt, kes kasvatab ja pakendab porgandeid IGA-le, METRO-le, LOBLAWS-ile jt

Väikesed kokteili(beebi)porgandid plastikkottides on tehtud suurematest kõveratest või deformeerunud porganditest, lastes neid läbi masinast, mis neid lõigub ja kujundab nad kokteiliporganditeks: enamik inimesi tõenäoliselt juba teab seda. 
Mida te ei pruugi teada, aga peaksite teadma, on järgmine: kui porgandid on lõigutud kokteiliporganditeks, pannakse nad vee ja kloori segusse, et nad säiliksid (see on seesama kloor, mida kasutatakse basseinivees), kuna neil ei ole enam neid kaitsvat naturaalset katet, siis on see klooridoos üsna suur. Te võite märgata, et iga kord, kui te hoiate neid oma külmkapis mõne päeva, tekib nende peale valge kiht, see ongi kloor, mis pinnale tuleb. Mis mõttega me riskime oma eluga, tarbides hea esteetilise välimusega juurvilju, mis on praktiliselt plastikust?

Me loodame, et see informatsioon jõuab võimalikult paljude inimesteni ja teavitab neid sellest, kust need porgandid tulevad ja kuidas neid valmistatakse. Kloor on hästi tuntud kartsinogeen.

Palun laske meie informatsioonil jõuda nii paljude inimesteni kui võimalik.

Kui te hoolite oma perest ja sõpradest, saatke see edasi.

Avalikku meediasse jõudis info miniporganite kahjulikkusest 2013. aasta algupoolel, aga tegelikult oli usaldamatus selle kauba vastu ning foon kuulujutu tekkeks olemas juba varem. Näiteks Pisiloomade Netipesa foorumis oli beebiporgandite kahjulikkus arutluse all juba 2009. aasta märtsis. Vestluse moderaator Nirgike kirjutas: "Loomaarst ütles, et merisigadele ei ole soovitav anda poes müüdavaid beebiporgandeid, kuna need on mürgiseid aineid täis (mõeldud siis just tööstuslikult toodetud beebiporgandeid, s.t. kui neid oma aias kasvatad, siis on okei)." "

Karoliina Vasli artikkel "Paanika internetis: kas beebiporgandid on kloorist läbiimbunud" ilmus Õhtulehes 7. jaanuaril 2013 ja sai 66 kommentaari (Vasli 2013). Nagu allpool toodud näidetest võib lugeda, oli ka selles diskussioonis nii vastu- kui ka poolthääli, negatiivset isiklikku kogemust omavaid inimesi, teadjaid ja sotsiaalmeedia ning meedia paanikakülvamisse kriitiliselt suhtuvaid arvajaid. Paljudel tarbijatel oli olemas isiklik kogemus beebiporganditega, mis külmkapis seismisel valkja kihi peale tõmbasid ja libedaks läksid, ning süüvimata toote valmistamise ja säilitamise tehnoloogiasse, süüdistasid nad tootjat. ${ }^{10}$

Olen poest mitu korda ostnud neid porgandeid, lõpptähtajani on aega veel küll aga osad porgandid on libedad ja käärind lõhnaga. Lahtine pakk samuti külmkapis järgmiseks päevaks libedaks läinud. Ei ole värske kraam! Häbi tootjale!!

Ma olen neid beebikaid ostnud ja päriselt ka tuleb paari päeva pärast mingi imelik kiht peale hoolimata sellest, et hoian neid külmikus. Olen 
ostnud eranditult Tallinna Kaubamajast-enam ei julge osta. Ostan parem tavalisi porgandeid. Isegi- kui ausalt öelda, siis konservporgand on etem, on teada, et sealt mingit mürgitust ei saa, ehkki on keemiat täis. Aga neid limaseid nn beebiporgandeid enam ei osta.

saime emaga kooritud porgandeid sü̈̈es mõelmad tugeva lööbe - emal läks lausa hing kinni sellest. õnneks oli zyrtec't käepärast.

Kahtlustati tootjapoolset salanõu, mis seisnes inimesele kahjuliku keemia kasutamises pealtnäha süütus ja tervislikus tootes, ning väideti, et eriliselt umbusklik tuleks olla igasuguste allahindluste suhtes, kus püütakse ostjale ebakvaliteetset kaupa maha müüa.

Kooritud porgandid ei näe välja nii, nagu need beebiporgandid. Igaljuhul on miski hull keemia mängus. Ka klooriga kraanivesi ei suuda kooritud porgandi pinda tumenemise eest kaitsta. Ükski normaalne inimene kooritud porgandit ei osta ka!

Kaubanduses saadav köögi- ja puuvilja kvaliteet on väga halb. Kui kaup on allahinnatud, siis on selleks ka põhjus. Kanarbiku tooteid enam ei osta ammu.

Teised kommenteerijad seevastu hindasid kohalikku tervislikku toodet ning suhtusid kriitiliselt interneti ja sotsiaalmeedia osasse tõsimeelsete teadmiste looja ja levitajana.

Teate, need, kes usuvad, et beebiporgand on kloorist läbiimbunud eriti veel Kadarbiku Talu toodang siis pangu ennast ... :P see ei vasta tõele!!! Tean täpselt mis ja kuidas need pakki pannakse. Beebiporgand on kõige õigem porgand mida võib julgesti näksida ilma, et kardaks kas tervis halveneb või hakkavad kõrvad kasvama:) Head isu!!!

jajah, kloori on ju ka joogivees.. Veel kord näide sellest, kuidas internet ja fb ei taga võluväel mingit suurt teadmist või rahvavõimu, vaid võib olla samahästi pinnaseks ka poriloopimisele ja lolluste levitamisele.

Kuigi tegemist oli rahvusvahelise jutuga, siis nagu eelnevatest kommentaaridest nähtub, kohanes see Eestis kiiresti ja sellele tekkis kohe ka ainus kohalik sihtmärk: tollal Eesti ainus beebiporgandite tootja Kadarbiku talu. Nii ülalmainitud Õhtulehe artiklis (Vasli 2013) kui järgmisel päeval Delfi Ärilehes ${ }^{11}$ ja Postimehe tarbijalehel ilmunud uudisloos (Kaukvere 2013) on seetõttu ka Kadarbiku porganditootja kommentaar: Kadarbiku talu juhid Veiko Pak ja 
Ants Pak ütlesid, et neil on kahju, et selline paanika levib, kuna beebiporgandid on ohutud. "Meie oma tootmisprotsessis koorime porgandi ja säilivuse andmiseks jahutame jäävees," kinnitas Veiko Pak. Peale nende kommentaaride jagas Kadarbiku talu infot beebiporgandite toote kohta ka oma Facebooki leheküljel "Kadarbiku köögivili": "Viimastel päevadel on hakanud levima kuuldus, et beebiporgandid on kahjulikud, kuna sinna lisatakse säilivuse tagamiseks kloori. Kahju, et selline paanika levib, sest tegu on täiesti ohutu Kadarbiku tootega. Meie oma tootmisprotsessis koorime porgandi ja säilivuse andmiseks jahutame jäävees. Meie toote säilivusaeg hoides temperatuuril $+2 \ldots+6^{\circ} \mathrm{C}$ on 8 päeva. Meie oma toodetes kloori ei kasuta. Iga kooritud toode tõmbub pikemal seismisel valkjaks, sest pind koorimisel kahjustub ning pigment saab välja tulla."12 Beebiporgandite ümber lahvatanud skandaal tipnes ETV 9. jaanuari "Ringvaate" saates, kus sai samuti sõna Kadarbiku talu esindaja Veiko Pak, kes kõik väited porgandite keemilise töötlemise kohta tagasi lükkas. ${ }^{13}$

Huvitav on see, et kuigi info hulk selle toote kohta internetis on küllaldane ja ilmselt kogu aeg suureneb, ${ }^{14}$ on tarbijate hulgas ikkagi sama aktuaalsed uskumused, mille tõttu on alust seda toodet mitte usaldada. Endiselt tuuakse esile põhjuseid, miks beebiporgandeid kui kaupa ja toiduainet ei saa usaldada, räägitakse väidetavast kloorisisaldusest ja valmistamise tehnoloogiast (rikenud või ebastandardsed juurviljad toorainena). Teisisõnu kahtlustatakse kasuahnete tootjate vandenõu pahaaimamatute tarbijate suhtes, kellele tervisliku toote pähe müüakse lõigutud keemiliselt töödeldud rämpsporgandeid. Üks kõnekamaid argumente keemilise töötlemise kohta on valkjas kiht, mis külmikus avatud pakis porganditele peale tekib. Nii nagu salatipesu kuulujutu puhul, oli beebiporgandite uudisfolklooris samuti esindatud nii irooniline kui ka humoorikas lähenemisnurk ning juttu klassifitseeriti nii ajakirjanduses kui ka sotsiaalmeedias mitmel korral linnalegendiks.

Illustratsioon 3. Sotsiaalmeedias levinud ineternetimeem beebiporgandite päritolust (www.naljakas.ee).

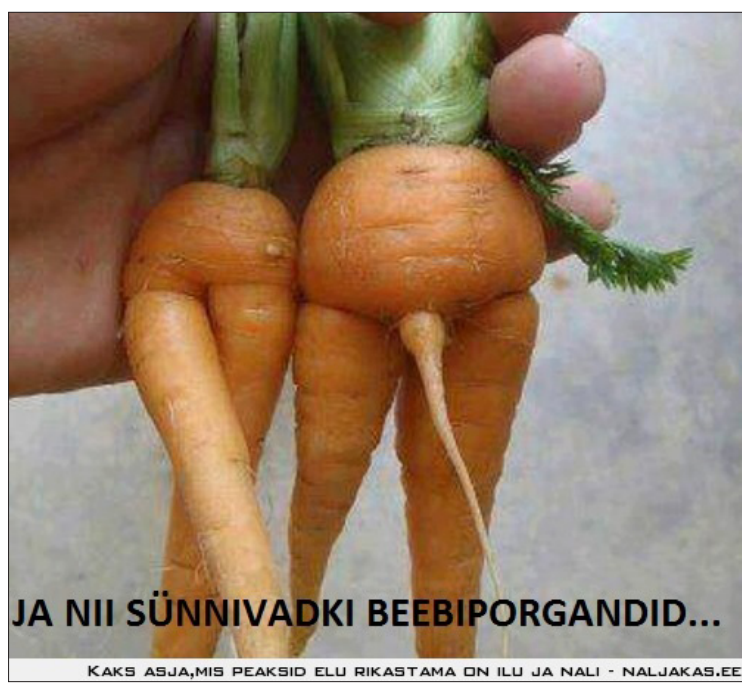


Need jagajad on parajad lollakad, kuna esiteks algallikas on USA päritolu ja snopes.com liigitab ka selle asjatu paanika alla ja teiseks tundub, et neil inimestel puudub iseseisva mõtlemise oskus. Mis iganes info tekitab kohe paanikat. Ootan juba, millal järjekordselt seda piparmündi keelustamise artiklit jagama hakatakse, iga poole aasta tagant teeb see tiiru ära ja igakord nn mõtlevad inimesed ohivad ja ägavad nii mis jube. (neiu52, 08.01.2013)

inimesed on lolliks läinud oma interneti ja facebookiga - ̈̈ks loll kirjutab ja tuhat lolli laigivad..... (kusti, 08.2013)

Kui seda ikka facebookis kirjutatakse, siis peab see tõsi olema. (seems legit, 08.01.2013)

pariisi kardulaid pestakse peale koorimist sääni jões, aga sääni vesi on ju teada... mõni isegi k.seb sinna jaaaaa! (jutt jumala tõsi, 08.01.2013)

OMG mul langesid juuksed välja ka kü̈̈s tuli maha kui neid sõin. (9321, 08.01.2013)

Kuulujutu moraliseeriv-õpetuslik jälgija aga leiab, et kuna poest ostetud töödeldud juurvili on kahtlase kvaliteediga ning kasumiahne tootja ja kauplus nõuavad ostjalt selle eest liiga kõrget hinda, on igal juhul targem osta kas mittetöödeldud kaupa või seda ise kasvatada ehk otsida usaldusväärsem müüja. Kogu see arutelu õhutas inimesi juurdlema ka tänapäeva suurenenud valikute ja muutunud toitumisharjumuste teemade üle.

Ei osta poest ega turult tundmatut petukaupa ja kellel mingigi võimalus muretsege kõik juurikad teada olevalt kasvatajatelt kes sama söövad! Hulgimü̈̈giks lisatakse kasvatamisel, säilimisel igasugu keemiat! Teatud juurikad säilivad teatud tingimustel oma aja, aga poelettidel mitte piisavalt kaua värskes välimuses. Sööme sisse keemiat ja jama, mille tagajärg pole teada! Kõige parem, kel võimalus, kasvatagu ise. Seda teed olen ise läinud. (Ainus soovitus!, 09.01.2013)

Vene ajal haisesid kõik kohad kloori järgi ja kõik olid terved nagu purikad. Pasanteeria oli väga haruldane. (muki, 09.01.2013)

ostab mullast kartulit ja koorimata porgandit! (Tark, 09.01.2013) 
Kloor klooriks, kuid kui paljud on vaadanud, kui suur on nende "beebiporgandite" (hea nipp turustamiseks selline armas nimi välja mõelda muide) ja tavaliste koorimata porgandite kilohindade vahe? See on kuskil 3-4 korda! Mille eest? Et oleks mugav maitsetuid suure südamikuga porgandeid väiksekstreituna snäkilauale panna? Soovitan selle asemel maitsvaid pärisporgandeid ja koorimisnuga osta. Kui veel neeger ka koorima palgata, saaks vist ikkagi odavamalt... (qwerty, 10.01.2013)

Kuulujutud formeeruvad, kinnistuvad ja käivituvad inimeste mälus tihtilugu mingite keeleliste ja tähenduslike assotsiatsioonide abil. On märgitud, et kaupade (ka asjade ja nähtuste) nimed ja (keelelisel kokkukõlal põhinevad) nimetused suudavad stimuleerida tugevaid (negatiivseid) kaastähendusi. (Kalmre 2008: 112; Turner 1993: 172) Seda eraldi aspekti võiks pidada silmas ka salatipesu ja beebiporgandite kuulduse formeerumise jälgimisel. Mõlemal juhul on nähtavasti tegemist ka kummagi keelelises ja tähenduslikus kokkukõlas peituva kahetise tähendusliku potentsiaaliga. Salatipesu assotsieerub mingis mõttes 'rahapesuga', kumbki tähendab pettust ja asjade tegeliku seisu varjamist, antud juhul siis poepettusi. Paljude kommentaaride kohaselt on beebiporgandite puhul vääriti mõistmist ja segadust põhjustanud just otse inglise keelest üle võetud ja selle kaubaartikli sisule eesti keeles mittevastav nimetus. Ostjatele võib seetõttu hämaraks jäädagi, kas nende porgandite puhul on tegemist beebitoidu, noore või väikese porgandiga, noorusväiksuse või sordiväiksusega. Tegelikult ei vasta ükski neist iseloomustustest kauba sisule. Otsene sisule vastav nimetus on inglise keeles baby-cut carrots, mille eestikeelseteks vasteteks võiksid olla tükeldatud ja kooritud porgandid, jupp-porgandid, porgandijupid või treitud porgandid. (Mäearu 2010) Nii et beebiporgandid viitaksid justkui millelegi väga süütule ja tervislikule, samal ajal kui üldise uskumuse kohaselt on nad tehtud hoopis ebastandardsest, isegi riknenud toorainest. Populaarse arvamuse kohaselt on kummalgi juhul tegemist pettusega.

\section{Kokkuvõtteks}

Jälgides kahe käsitlusaluse kuulujutu kulgu erinevates keskkondades võib konstateerida, et kaubanduslike legendide ja kuulujuttude puhul käivitub suulises suhtluses, ajakirjanduses ja sotsiaalmeedias omamoodi teadmiste loomise protsess, milles oma osa etendavad mälestused, uskumused ja stereotüübid, nali, skeptitsism ja ignorantsus. Kusjuures ka kolmel viimasel on selles protsessis väga oluline roll, sest nii legendid kui ka kuulujutud saavadki eksisteerida 
tänu "vale” ja “õige” kestvale debatile. Hans-Joachim Neubrauer iseloomustab internetti kui kuulujuttu digitaalses vormis. Koos internetiga saabus kuulujutu suurajastu. Internetis levivad kinnitamata kuuldused anonüümselt läbi paljude suude, need jutud korjab üles televisioon, raadio, kirjutav ajakirjandus, kus need kuuldused muutuvad uudisteks, mis üritavad seletada, aga ka dramatiseerivad asjaolusid ning jälgivad sündmusi päev päevalt. (Neubrauer 1999: 151, 153 jm) Sedasama fenomeni võib jälgida ka kahe kõnealuse kuulduse puhul.

Kuulujuttudele tüüpilise toimimisidee kohaselt toimus mõlemal juhul selle sobitumine ehk assimileerumine vastuvõtjate maailmapildiga. Ehk siis selleks, et varitsevast ohust paremini aru saada, seostati seda kohaliku tootja või müüjaga. Beebiporgandite puhul Kadarbiku taluga ning salatipesu puhul kohalike kauplustega. Kohalik salatipesu kuuldus tõi esile eestlaste konservatiivse ajaloolise mälu ning sellest tulenevate vastandustega seotud uskumused. Huvitav oli see, et kuigi negatiivseid näiteid toodi nii Eestis olevate poekettide Selveri, Maxima, Konsumi ja Rimi toiduvõltsimise kohta, eristus nendes netidiskussioonides põhilise sihtmärgina ainuke eesti kohalikul kapitalil ja suures osas ja kohalikku kaupa müüv poekett - Grossi Toidukaubad, mis kuulub Virumaalt pärit ärimehele Oleg Grossile, kes omamoodi esindas ja koondas kommenteerijate silmis mälestust ja isiklikke kogemusi nõukogude aja tootmisest, tarbimisest ja teeninduskultuurist. See sihtmärk valiti ilmselt nagu mitmete teiste eestlaste konservatiivsele ajaloolisele mälule tuginevate kuulujuttude puhul - nimelt ajaloost tulenevate vastanduste alusel. ${ }^{15}$

Mõlema kuulujutu tsüklid toovad küllap esimest korda Eestis nii ulatuslikult esile tootjate ja kaubanduskettide mõjuvõimu, kokkuleppe ja usaldamatuse teema. Siin on ühel kaalukausil müüjate ja tootjate kasumisoov ning teisel heaoluühiskonna suhteliselt jõukate tarbijate aktuaalse elustiili (piiratud ajaressurss, pidev tervislikkuse jälgimine) surve ning sellestsamast survest põhjustatud frustratsioon, usaldamatus ja kartused.

Teisiti öeldes toovad need kaks kuulujututsüklit esile konflikti tänapäeva kapitalistliku tarbimisühiskonna ja infoühiskonna vahel. Kusjuures kuulujuttude tekkimise ajendiks on tänapäeval sageli mitte infopuudus, mida senini valdavalt on peetud kuulujuttude tekkimise põhjuseks, vaid info ja arvamuste üleküllus, üheselt mõistetava info puudus.

Toiduajakirjanik Margit Tõnson, arutledes tänapäeva inimese suhete üle toidusse, möönab: “Oma eluga hästi toimetulev 21. sajandi eurooplane elab justkui bipolaarses kultuuriruumis - ühelt poolt on toitu, millega ennast lohutada, turgutada ja töös hoida, külluses, selle tarbimiseks on tal ka rohkem aega ja raha kui esivanematel. Teisest küljest ei ole ta kunagi varem nii palju pead murdnud iga kahvlitäie üle, mis tema suhu jõuab - on see ikka tervislik 
ja kasulik, geneetiliselt muundamata ja mahe? Seda vastuolu toetab ühelt poolt kapitalistlik tarbimisloogika - mida rohkem me tarbime, seda rohkem saab toota, seda suurem on omanikutulu ja seda paremini kõigil läheb - ja teiselt poolt infoühiskond, kus põhjalik ja mitte alati mustvalge ning üheselt mõistetav info iga toote ja tootja kohta on paari hiirekliki kaugusel” (Tõnson 2013).

\section{Kommentaarid}

1 Artikkel on seotud teemaga "Folkloori narratiivsed ja usundilised aspektid" (IUT22-5).

${ }^{2}$ Folkloristikas on ingliskeelse sõna legend ajalooliseks vasteks Eesti traditsioonis olnud 'muistend'. Kuigi pärast Teist maailmasõda esile kerkinud modernset aega käsitlevate juttude juured võivad peituda varasemas ajas, on tegemist siiski moodsa aja inimeste vajadustest tingitud juttudega, mille tähistamiseks on kasutusele võetud urban legend, contemporary legend - eesti keeles 'linnamuistend', 'tänapäeva muistend'. Populaarse terminina on avalikus meedias kasutusel 'linnalegend'. Viimast eelistab ka artikli autor, loobudes selle materjali puhul minevikulisust rõhutavast 'muistendist'. Lühematel kuulujuttudel ja rohkem moodsaid jutumotiive sisaldavatel legendidel on sarnased levikumeediumid, nad kattuvad osalt ka sisus ning väljendavad mingit üldist uskumust käsitledes neid eluvaldkondi, mis võivad olla ebaselged ja ärevust tekitavad. Legendi ja kuulujutu karakteristikatest vt Kalmre 2008: 28-30.

3 Tegelikult on ajakirjanduse käitumisest Rootsis 1978. aastast olemas ka vastupidine näide. Jutt on Palestiina organisatsiooni poolt ringlema lastud poliitilise eesmärgiga kuuldusest, justnagu sisaldaksid Iisraelist pärit apelsinid elavhõbedat. Kuuldus levis paljusid meediaväljaandeid pidi ka Rootsi, kus kaks õhtulehte - Expressen ja Aftonbladet - selle uudise edastamisel erineva positsiooni valisid. Esimene toetas Iisraeli ja teine Palestiinat. (Klintberg 1983: 159)

${ }^{4}$ Foon kuulujutu tekkeks oli juba varem olemas. Tõenäoliselt esimene põhjalikum artikkel salatipesemise teemal ilmus 2006. aastal (Taim 2006). Blogis Tark Ostja viidatakse 2008. aastal ilmunud Õhtulehe artiklile salatipesu kohta, mis ei olnud käesoleva artikli kirjutamise ajaks enam leitav. Vt https//tarkostja.wordpress. com/2010/03/03/linnalegend-kas-poodides-pestakse-salateid/.

5 Kommentaarid on salvestatud Kristiina Kruuse artikli ilmumise järel. Artikli kirjutamise ajal, 13. veebruaril 2015, pole need enam nähtavad.

${ }^{6}$ Linnalegendide ja kuulujuttude ambivalentsest olemusest vt nt Lindahl 1986; Kalmre 2008: $114-115 \mathrm{jt}$.

7 Eestis on selle kauba nimetusena valdavalt käibel 'beebiporgandid'.

8 World Carrot Museum (http://www.carrotmuseum.co.uk/babycarrot.html - 12. veebruar 2015).

$9 \mathrm{Vt} \mathrm{http://www.pisi.ee/viewtopic.php?f=45 \& t=7833} \mathrm{(vaadatud} \mathrm{13.} \mathrm{veebruar} \mathrm{2015).}$

${ }^{10}$ Kommentaarid on salvestatud Karoliina Vasli artikli ilmumise järel. Artikli kirjutamise ajal, 13. veebruaril 2015, pole need enam nähtavad.

11 Uudis sisaldab 53 kommentaari (http://arileht.delfi.ee/archive/paanika-internetis-kasbeebiporgandid-on-kloorist-labiimbunud.d?id=65503658 - 13. veebruar 2015). 
${ }^{12} \mathrm{https}: / /$ www.facebook.com/permalink.php?story_fbid=10151227011471864\&id=1826 $11991863 \&$ fref $=\mathrm{nf}-19$. veebruar 2015.

${ }^{13}$ Saade ei ole enam järelvaadatav, info saate kohta: https://www.facebook.com/ lapsjapere/posts/408072385940297 - 13. veebruar 2015.

${ }^{14}$ Pidasin oma esimese ettekande sel teemal 2013. aasta alguses folkloristide talvekonverentsil (Kalmre 2013). Vahepealsel ajal on juba esmase vaatluse kohaselt tähelepanuväärselt suurenenud beebiporgandite toodet ja tootmist tutvustava ingliskeelse materjali hulk internetis (Google, Youtube jm).

${ }^{15}$ Vt Kalmre 2008: 84, 94 jm.

\section{Kirjandus}

Allport, Gordon W. \& Postman, Leo 1947. The Psychology of Rumor. Henry Holt and Company: New York.

Bell, L. Michael 1976. Cokelore. Western Folklore 35, lk 59-64 (doi: 10.2307/1499155).

Domowitz, Susan 1979. Foreign Matter in Food: A Legend Type. Indiana Folklore 12, lk 86-95.

Fine, Gary Alan 1979. Cokelore and Coke Law: Urban Belief Tales and the Problem of Multiple Origins. Journal of American Folklore 92, lk 477-482 (doi: 10.2307/540512).

Fine, Gary Alan 1985. The Goliath Effect. Corporate Dominance and Mercantile Legends. Journal of American Folklore 98, lk 63-84 (doi: 10.2307/540877).

Hein, Inna Katrin 2013. Suurbritannias on hobuseliha skandaali tõttu toimunud arreteerimisi. Postimees 15.02.2013 (http://elu24.postimees.ee/1138548/suurbritanniason-hobuseliha-skandaali-tottu-toimunud-arreteerimisi - 13. veebruar 2015).

Kalmre, Eda 2008. Hirm ja võõraviha sõjajärgses Tartus. Tänapäeva folkloorist 7, Tartu: EKM Teaduskirjastus.

Kalmre, Eda 2013. Beebiporgandid ja salatipesu - kaubanduslikud muistendid ja kuulujutud Eesti tarbimisühiskonnas. Folkloor linnas ja linnast. VIII folkloristide talvekonverents 28. veebruaril - 1. märtsil 2013 Tallinna Ülikoolis. Tartu \& Tallinn: EKM Teaduskirjastus, lk 11-12.

Kaukvere, Tiina 2013. Kadarbiku: beebiporgandeid ei leotata kloorivees. Postimees 8.01.2013 (http://tarbija24.postimees.ee/1096036/kadarbiku-beebiporgandeid-ei-leotatakloorivees - 13. veebruar 2015).

Klintberg, Bengt af 1981. Modern Migratory Legends in Oral Tradition and Daily Papers. ARV. Scandinavian Yearbook of Folklore 37, lk 153-160.

Kruuse, Kristiina 2012. Salatipesu miljoniline leiutasu ootab siiani. Linnalegendid ajavad toidutootjad naerma. Linnalegendid šokeerivad tõepäraga. Postimees 21.02.2012 (http://pluss.postimees.ee/746206/salatipesu-miljoniline-leiutasu-ootab-siiani - 13. veebruar 2015). 
Langemets, Andres 1999. Infoühiskonna tulek Eestisse. Sirp 1. aprill (http://www.sirp. ee/archive/1999/01.04.99/Sots/sots1-3.html - 24. märts 2015).

Lindahl, Carl 1986. Psychic Ambiguity at the Legend Core. Journal of Folklore Research 23 (1), lk 1-21.

Lucas, Louise 2013. Hobuseliha skandaal puhub tuult Fairtrade tiibadesse. Postimees 26.02.2013 (http://majandus24.postimees.ee/1150382/hobuseliha-skandaal-puhub-tuultfairtrade-i-tiibades - 24. märts 2015).

Mets, Anna-Liisa (toim) 2011. Oleg Gross pakub salatipesu tõestajale miljonit. Õhtuleht 19. oktoober (http://www.ohtuleht.ee/448376/oleg-gross-pakub-salatipesu-toestajalemiljonit - 13. veebruar 2015).

Mäearu, Sirje. Toidusõnad sihikul (http://www.emakeeleselts.ee/omakeel/2010_1/ OK_2010-1_07.pdf - 24. märts 2015).

Neubauer, Hans-Joachim 1999. The Rumor. A Cultural History. London: Free Association books.

Ojaperv, Aivar 2011. Kuulutaja 14.10.2011 (http://www.ogelektra.ee/index.php/en/ uudised/kuulutaja/153-lambipirnidega-alustanud-og-elektral-taitus-kakskummend 13.veebruar 2015).

Reporter 2013. Hobuseliha skandaal jätkub. Kanal 2. Reporter 05.03.2013, online (http:// www.reporter.ee/2013/03/05/hobuseliha-skandaal-jatkub/ 13. veebruar 2015).

Russell, Frank 2011. Newslore. Contemporary Folklore in the Internet. University Press of Mississippi/Jackson.

Taim, Krista 2006. Kas poodides töötavad salatipesijad? Delfi. Äripäev 6. jaanuar (http:// arileht.delfi.ee/archive/kas-poodides-tootavad-salatipesijad?id=11946363 - 24. märts 2015).

Turner, Patricia A. 1993. I heard it through the grapevine: Rumor in African-American culture. Berkeley, CA: University of California Press.

Tõnson, Margit 2013. Nälg armastuse järele. Eesti Ekspress 14. veebruar (http://ekspress. delfi.ee/news/areen/areeni-kaanelugu-nalg-armastuse-jarele?id=65676888 -24 . märts 2015).

Vasli, Karoliina 2013. Paanika internetis: kas beebiporgandid on kloorist läbiimbunud? Õhtuleht 7. jaanuar (http://www.ohtuleht.ee/505529/paanika-internetis-kas-beebiporgandidon-kloorist-labiimbunud-24. märts 2015). 


\title{
Summary
}

\section{Fast and Healthy Food - Could it Be Trusted? \\ Commercial Rumours in Present-Day Consumerist Society}

\author{
Eda Kalmre
}

Keywords: belief, commercial legend, conspiracy theory, fake food, healthy diet, newslore, rumour

The article gives an overview of the formation and origin of two food-related rumour cycles that have circulated in Estonia, various viewpoints and opinions about presentday consumption and trade, which have been highlighted in these rumours, discussions, comments in discussion forums and articles, as well as of people's problems, fears, and stereotypic beliefs. The first commercial rumour about salad rinsing and other commercial frauds is of Estonian origin. Namely, in 2006 a rumour started to circulate in Estonian social networks and later on also in newspapers that local store chains were selling salads past the expiration date, with the spoiled dressing washed out and replaced with fresh. The second rumour, most probably of USA origin, was associated with international market and trade and began to spread in Estonia at the beginning of 2013, through a chain letter disseminated in social networking sites, warning people about the harmfulness of baby carrots. 